\title{
USING OF P/E AND P/BV INDICATORS BY BUILDING A STOCK PORTFOLIO
}

\author{
[Využití indikátorů P/E a P/BV při sestavení akciového portfolia] \\ Martin Širůček ${ }^{1}$, Martin Surovec ${ }^{2}$ \\ ${ }^{1}$ Mendelova univerzita v Brně, Provozně ekonomická fakulta, Zemědělská 1, 61300 Brno \\ Email:sirucek@gmail.com \\ ${ }^{2}$ Mendelova univerzita v Brně, Provozně ekonomická fakulta, Zemědělská 1, 61300 Brno \\ Email: surovecmartin@gmail.com
}

\begin{abstract}
Presented paper is dealing with using selected fundamental indicators by building a stock portfolio. Analysis is focused on using $\mathrm{P} / \mathrm{E}$ and $\mathrm{P} / \mathrm{BV}$ indicators by building a stock portfolio from stocks listed on Prague Stock Exchange. The aim of this paper is answer on question, if stocks with lower $\mathrm{P} / \mathrm{E}$ and/or P/BV bring investor higher return than stocks with higher values of these indicators or not. The usability of indicators was confirmed by our findings. Another conclusion of this paper is finding that stocks with lower P/E and/or P/BV exceeded benchmark represented by index PX-TR. Observed time period was from 2004 till 2014. Selected period was also divided on 5 year slip periods. Results show that stock with lower P/E or P/BV bring higher profit than stock with higher P/E or P/BV. These stocks also exceeded the benchmark.
\end{abstract}

Keywords: fundamental analysis, fundamental indicators, indicator ratio, price book value, price earning.

JEL classification: G11, G12

Doručeno redakci: 22.3.2017; Recenzováno: 29.3.2017; 12.4.2017; Schváleno k publikování: 31.5.2017

\section{Úvod}

Existuje několik př́stupů, jak posuzovat, zda je cena akcií př́iznivá. Těmi základními jsou fundamentální (hodnotová), technická a psychologická analýza. Není snadné určit, která z nich je lepší nebo horší a vedou se o tom dlouholeté spory, ale existují i zastánci kombinace těchto př́stupů. Nicméně vzhledem k provedeným výzkumům (Helmann 2000, Vergossen 1993 či Pike et al. 1993), významnou roli stále zaujímá fundamentální analýza. Význam fundamentů potvrzuje např. i Dell'Ariccia a kol. (2013), kteří potvrdili vliv zpožděného růstu HDP na kreditní boom či Claessens a kol. (2010), kteří potvrdili výrazný nárůst ceny aktiv (nemovitostí a cenných papírů) vlivem př́livu kapitálu do ekonomik. Obecně uvedení autoři potvrzují silný vliv pohybu mezinárodního kapitálu na národní ekonomiky a trhy.

Fundamentální analýza se zaměřuje na fakta o analyzované společnosti, které utváŕí hodnotu společnosti a mají vliv na cenu akcií. Nejsledovanější jsou pochopitelně informace o zisku, tržbách či krátkodobém a dlouhodobém dluhu. Mnoho investorů se shoduje, že má význam sledovat základní ukazatele jako je cena $\mathrm{k}$ zisku společnosti na jednu akcii (price to earnings, $\mathrm{P} / \mathrm{E}$ ), cena $\mathrm{v}$ poměru $\mathrm{k}$ tržbám na jednu akcii (price to sales, $\mathrm{P} / \mathrm{S}$ ), cena $\mathrm{v}$ poměru $\mathrm{k}$ účetní hodnotě vlastního kapitálu společnosti (price to book, $\mathrm{P} / \mathrm{BV}$ ) nebo ukazatele zadluženosti a běžné likvidity. Existuje množství výzkumů, které podporují nebo vyvracejí použitelnost těchto ukazatelů v různých jejich obměnách. Siegel (2014) ukazuje na nadvýnos akcií s nízkým P/E v následujícím desetiletém období proti akciím s vysokým P/E na americkém trhu za období 1957 - 2012. Davis, Aliaga-Diaz a Thomas (2012) ve své studii potvrdili, že výše běžného P/E dokáže vysvětlit 38 \% rozptylu následujících desetiletých výnosů (nižší P/E znamená následné 
vyšší výnosy). Damodaran (2003) potvrzuje nadvýnos akcií s nízkým P/BV v období 1927 2001, avšak s nižší použitelností této strategie v dobách krize.

Je možné využít vybrané indikátory fundamentální analýzy k provádění stock pickingu? Potvrdí se i výsledky $z$ amerického trhu na české burze? Odpovědi na tyto otázky přináší následující př́spěvek, jehož cílem je na základě provedených empirických výpočtů a analýz doporučit investorům na tuzemském akciovém trhu, zda používat/nepoužívat fundamentální poměrové ukazatele $\mathrm{P} / \mathrm{E}$ (price to earning ratio) a $\mathrm{P} / \mathrm{BV}$ (price to book ratio) při rozhodování o zařazení určitého titulu do akciového portfolia.

V souladu s cílem příspěvku byly stanoveny následující hypotézy:

1. Akcie na českém trhu s nízkým poměrem $\mathrm{P} / \mathrm{E}$ překonávají trh a přinášejí investorovi vyšší průměrný roční reálný výnos než akcie s vysokým poměrem $\mathrm{P} / \mathrm{E}$.

2. Akcie na českém trhu s nízkým poměrem $\mathrm{P} / \mathrm{BV}$ překonávají trh a přinášejí investorovi vyšší průměrný roční reálný výnos než akcie s vysokým poměrem $\mathrm{P} / \mathrm{BV}$.

\section{Analýza stávajícího stavu}

Fundamentální analýza je základní akciovou analýzou, kterou investor provádí při svém investičním rozhodování. Jejím cílem je odhalit, které akcie jsou na trhu nadhodnoceny či podhodnoceny a podle toho prodávat či nakupovat. Význam fundamentální analýzy potvrzuje i Helmann (2000), Veselá (2011) či Širůček (2015).

Tabulka 1: Frekvence používání analytických metod v České republice

\begin{tabular}{|l|c|}
\hline Druh použité analýzy & Použití téměř vždy $(96-100 \%)$ \\
\hline Fundamentální analýza & $81,25 \%$ \\
\hline Technická analýza & $35,48 \%$ \\
\hline
\end{tabular}

Zdroj: Veselá (2011)

Fundamentální analýzu lze provádět ve třech základních úrovních - analýza globální, odvětvová a mikroekonomická (firemní). Vzhledem k zamření příspěvku je pozornost věnována zejména firemní fundamentální analýze.

Z držby akcií investorovi plynou dva druhy výnosu. Prvním jsou dividendy po celou dobu držby akcie (čtvrtletně, pololetně nebo ročně), druhým je kapitálový výnos, což je rozdíl prodejního kurzu a kurzu nákupního. Výstupem firemní (mikroekonomické) fundamentální analýzy je tzv. vnitřní hodnota, která je subjektivně stanovena každým investorem. Definici vnitřní hodnoty přináší např. Nitzsche, Cuthbertson (2008), kteří ji uvádějí jako spravedlivou hodnotu, teoretickou dnešní hodnotu budoucího cashflow (dividenda, prodejní cena), které odhadujeme, že držba aktiva přinese. Tato vnitřní hodnota je ovlivňována „fundamenty“, tj. ekonomickými proměnnými, které ovlivňují např́íklad budoucí výplatu dividend nebo strategii podniku.

Vnitřní hodnota je závislá na fundamentech (zisk na akcii, tržby aj.), které jsou zpravidla reportovány společností čtvrtletně. S tím souvisí, že se vnitřní hodnota mění mnohem méně často než samotná cena akcie, která se mění na základě nabídky a poptávky v obchodních hodinách téměř nepřetržitě. Aktuální tržní cena akcie tedy kolísá kolem své vnitřní hodnoty $\mathrm{v}$ čase. 


\subsection{Využití ukazatele $P / E$ při výběru akcií do portfolia}

Siegel (2014) uvádí, že výzkum ukazatele P/E začal v pozdních 70. letech, kdy Sanjoy Basu, zjistil, že akcie s nízkým $\mathrm{P} / \mathrm{E}$ svými budoucími výnosy významně překonávají společnosti s poměrem vysokým a to i po započtení rizika. Basu uvádí, že investoři, kteří jsou zvyklí investovat do akcií dražších než $\mathrm{P} / \mathrm{E}=16 \mathrm{v}$ dlouhém období pravděpodobně ztratí významnou část finančních prostředků. Obdobné stanovisko zaujímá Shen (2000), který uvádí, období, kdy akci prŕíp. celý trh s vysokým $\mathrm{P} / \mathrm{E}$ bývá následováno obdobím $\mathrm{s}$ nízkým výnosem a výkonem trhu. Současně ale upozorňuje na nemožnost předvídat budoucí vývoj na základě historických dat (potvrzuje neopakování historie).

Jinou studii provedli Davis, Aliaga-Diaz a Thomas (2012). Autoři zkoumali pro index S\&P 500 za pomocí lineárního regresního modelu, jak velkou část následných desetiletých reálných výnosů dokáže vysvětlit výše běžného P/E a Shillerova P/E za období 1926-2011. Za pomocí Shillerova $\mathrm{P} / \mathrm{E}$ model vysvětlil $43 \%$ rozptylu následných desetiletých výnosů, v př́padě běžného $\mathrm{P} / \mathrm{E}$ to bylo $38 \%$. Mnohem horších výsledků dosáhly modely při předpovědi následného jednoletého výzkumu, kdy pouze $8 \%$ rozptylu vysvětleno za pomoci indikátoru Shillerovo $\mathrm{P} / \mathrm{E}$ a $3 \%$ pomocí běžného $\mathrm{P} / \mathrm{E}$. To jasně poukazuje na fakt, že krátkodobý pohyb akcií lze za pomoci fundamentální analýzy opravdu jen stěží předvídat. Důležitým závěrem dané studie je také fakt, že z celkových 15 indikátorů si jednoznačně nejlépe vedlo Shillerovo $\mathrm{P} / \mathrm{E}$ a běžné P/E. Podobné výsledky uvádějí Bhargava, Malhotra (2006), kteří výzkumem na indexu S\&P500 či MSCI World došli k závěrům, že hodnoty ukazatele P/E za celý trh nemají vliv na budoucí ceny a výnosy akcií. Damodaran (2003) zkoumal použitelnost ukazatele P/E na indexu S\&P 500 v období 1952-2001. Akcie rozdělil do skupin podle výše P/E a dospěl $\mathrm{k}$ závěru, že akcie $\mathrm{z}$ decilu $\mathrm{s}$ nejnižším $\mathrm{P} / \mathrm{E}$ překonaly průměrným ročním výnosem decil s nejvyšším P/E o 9 - 10 p.b. Vorwerg (2015) zkoumal německý akciový trh v období 20042014. Obdobně rozdělil akcie do tř́ skupin podle výše P/E. Akcie s P/E nižším než 11,63 považuje pro účel své práce jako hodnotové, akcie s $\mathrm{P} / \mathrm{E}$ vyšším než 19,82 považuje za růstové. $\mathrm{V}$ jeho studii rovněž hodnotové akcie překonaly ty růstové, konkrétně o 4,3 \%, i když test nepotvrdil statistickou významnost těchto výsledků. Knopers (2014) zkoumal index Euronext v období 1995-2013. Hodnotové akcie, které tvořily akcie s nejnižším $\mathrm{P} / \mathrm{E}$, překonaly průměrným ročním výnosem trh za celé období o 4,15 p.b. (výnos $12,61 \%$ proti 8,46 \%). Existují další výzkumy i z jiných částí světa než USA a Evropy, například z Japonska. Tarazi, Ahmad (2012) zkoumali schopnost předvídat budoucí výnosy více ukazatelů včetně ukazatele P/E na Tokijské burze za období 2000-2010. Uvádí, že vysoká úroveň P/E má silný negativní dopad na budoucí úroveň výnosů.

Srovnání amerického trhu s pražskou burzou přináší Vorek (2009), který se zaměřil na vývoj $\mathrm{P} / \mathrm{E}$ indexu S\&P 500 a indexu PX v průběhu krize. Podle něj byli ochotni investoři na českém i americkém trh zaplatit ještě v polovině roku 2007 cenu odpovídající 17-násobku zisku na akcii. Zatímco na americkém trhu již v záŕí 2007 hodnota P/E poklesla na 12, v Praze byl pokles pomalejší a uvedené hodnoty dosáhl trh až v březnu 2008. Výsledkem tedy je, že v období předcházející krizi (optimismus, býčí trend) jsou investoři ochotni platit vyšší násobky zisku na akcii, které v průběhu krize (v př́padě amerického trhu rychle) klesají.

Ukazatel P/E investorovi říká, jaký násobek zisku na akcii je aktuálně za danou akcii ochoten zaplatili. Platí, že čím vyšší násobek zisku za akcii jsou investoři ochotni platit, tím více si dané akcie cení a akcie je tedy relativně dražší, je po ní velká poptávka. Obvykle jsou tyto dražší akcie spojeny s vyšším historickým a očekávaným růstem zisků, které relativní drahost kompenzují. Ukazatel P/E může být okamžitě použit k rozhodnutí, zda je akcie podhodnocená nebo nadhodnocená, kdy investor vypočítá běžné $\mathrm{P} / \mathrm{E} \mathrm{k}$ danému datu, nebo např́íklad ze zisků 
za poslední tři roky a vytvoří z těchto hodnot aritmetický průměr, aby vyhladil sezónní výkyvy. Výši hodnoty vyhodnotí okamžitě na základě všech faktorů, které k dané investici má. Může se jednat o velmi širokou škálu informací, které dokáže správně vyhodnotit pouze zkušený investor.

Nejprve můžou být zvažovány faktory globální: kurzotvorné makroekonomické informace, zda ekonomika roste nebo klesá; politické riziko, které např́iklad velmi ovlivňuje výši P/E ruských společností, kde $\mathrm{P} / \mathrm{E}$ dosahuje extrémně nízkých hodnot. $\mathrm{V}$ určitých situacích je třeba zvážit např. i ekologické hledisko, kdy můžou nová vydaná ekologická opatření ohrozit současný byznys. Dle Siegel (2002) je významným faktorem, proč jsou lidé ochotni zaplatit obecně větší násobky EPS za akcii, nízká inflace a nízké úrokové míry. V takové situaci standardní investiční instrumenty jako obligace přináší nízké a někdy i záporné výnosy. Výsledkem je, že investoři dají přednost akciím, vzroste poptávka a tím i relativně cena k zisku na akcii (earnings per share, EPS).

Rozhodování o nákupu či prodeji akcie na základě hodnoty ukazatele P/E lze i díky její analýze v čase. Thomsett (2006) doporučuje studovat vývoj hodnoty P/E za větší množství let, zda je hodnota stabilní, nebo naopak velmi kolísá. Vhodné je sledovat hodnotu P/E 4x ročně a pro každý rok do grafu zanést nejvyšší a nejnižší hodnotu, které bylo dosaženo. Pokud je výsledné pásmo relativně úzké a př́liš nekolísá a je taktéž podpořeno stabilním pásmem tržní ceny akcie (je tvořeno na stejném principu), autor to považuje za znamení, že je akcie s velkou pravděpodobností bezpečná dlouhodobá investice. Problém nastává, pokud společnost v některých letech dosáhne ztráty. Pokud je to pouze výjimečně, může se hodnota pro dané období vyloučit jako extrém, podobně jako ve statistice. Pokud je to častěji, bude vhodnější místo poměru $\mathrm{P} / \mathrm{E}$ použít ukazatel price to sales, tržní hodnota akcie k tržbám $(\mathrm{P} / \mathrm{S})$, kde tržby ve jmenovateli vykazují mnohem menší variabilitu než čistý zisk.

Výpočet ukazatele $\mathrm{P} / \mathrm{E}$ se skládá z aktuální ceny akcie $\mathrm{k}$ datu, pro které ukazatel počítáme (čitatel) a zisku na akcii (jmenovatel). Cena akcie je daná, a tudíž se dále nijak nemění. Upravit správně zisk na akcii však může být u určitých společností téměř neřešitelným problémem i pro velmi zkušené investory.

Na celou řadu podobných problémů se správným zařazením výnosů a nákladů poukazuje ve své práci také Thomsett (2006). Investoři dávají přednost společnostem, které mají stabilní a v čase rostoucí zisk před společnostmi, které vykazují vysoce volatilní výsledky hospodaření. To i v situaci, kdy je celkový trend velmi kolísavých výsledků pozitivní. Toho jsou si účetní společností moc dobře vědomi a mnohdy manipulují s výnosy a náklady tak, aby výsledný čistý zisk „vyhladili“ v čase. Tím však porušují jedno ze základních pravidel účetnictví, které říká, že každá položka musí být v účetnictví zařazena do období, kterého se týká.

Další nevýhodou běžného P/E je, že ve výpočtu je uvažován zisk společnosti, bez ohledu na to, zda byl vytvořen z hlavní činnosti podniku nebo ne. Pokud se ve výkazu zisku a ztráty neobjevuje př́iliš mnoho položek $\mathrm{z}$ jiných než hlavních činností podniku a jsou to relativně malé sumy, není problém. Pokud se však ve výkazu objevují s železnou pravidelností obrovské mimořádné položky, investor čelí vážnému problému, který musí řešit.

Řešením může být využití tzv. core earnings. Jedná se o specifickou úpravu čistého zisku, kdy je výsledkem zisk, který se týká pouze hlavní činnosti (jádra) společnosti. Thomsett (2006) uvádí, že úprava jádrového zisku může být různorodá a docela komplexní. Avšak hlavní úprava zahrnuje poměrně malý počet položek: kapitálové zisky nebo ztráty, zisk z prodeje pobočky 
nebo celé divize a jednorázové změny v účetnictví. Výsledkem je potom tzv. Shillerovo P/E, nazýváno též cyclically adjusted price to earnings ratio, CAPE. Vypočítáním Shillerova P/E místo běžného P/E dosáhneme také lepšího obrazu o aktuální „drahosti“ celého indexu. Siegel (2016) však ve svém článku upozorňuje, že se v roce 1990 určitým způsobem změnily praktiky v americkém účetním standardu GAAP. Uvádí, že nové praktiky posunuly zisky společností v obdobích krize mnohem níže, než byly kdykoliv předtím. Protože Shillerovo P/E počítá s desetiletými zisky, budou veškeré hodnoty Shillerova P/E nadhodnocené (až do let 2018-19. Alternativu spatřuje ve využití NIPA (national income and product account) ve jmenovateli vzorce pro výpočet $\mathrm{P} / \mathrm{E}$.

\subsection{Využití ukazatele P/BV při výběru akcií do portfolia}

V zahraniční literatuře existuje velké množství výzkumů na téma, že hodnotové akcie (myšleno akcie s nízkými hodnotami $\mathrm{P} / \mathrm{E}, \mathrm{P} / \mathrm{BV}$ apod.) přináší vyšší výnos než ,žhavé“ akcie, které se obvykle vyznačují vysokým růstem zisku na akcii v minulosti a dalším očekávaným růstem v budoucnosti. Lakonishok, Shleifer, Vishny (1994) to vysvětlují tím, že investoři se obvykle zaměřují právě na akcie s velkorysými výsledky z minulosti a extrapolují je do daleké budoucnosti, aniž by tuto extrapolaci důsledně podpořili fakty. Výsledkem je př́lišné nadhodnocení rostoucích akcií a stejně tak i podhodnocení akcií, které v minulosti neukázaly př́liš dobré výsledky. Potvrzují to také De Bondt a Thaler (1985), kteří poukazují na nadměrný výnos akcií, které v posledních třech vykázaly nejnižší výnosy a naopak. V jejich výzkumu akcie s nízkým výnosem za poslední tři roky ukázaly v následcích 60 měsících kumulativní nadvýnos přibližně $30 \%$, zatímco akcie s vysokým výnosem za poslední tři roky vykázaly za následujících 60 měsíců kumulativní podvýnos $10 \%$ proti očekávanému výnosu za použití modelu CAPM.

Lakonishok, Shleifer, Vishny (1994) zkoumali vždy pětileté výnosy 2700 akcií po pětiletých intervalech mezi léty 1968 až 1989 . Obrovské množství akcií seřadili do deseti skupin od akcií s nejnižší hodnotou P/BV po nejvyšší (číslo 10 jsou tedy hodnotové akcie, číslo 1 jsou podle fundamentální analýzy předražené akcie). Z provedeného výzkumu vidíme, že akcie s nejvyšším P/BV vykázaly o 7,8 p.b. nižšś výnosy než akcie s nejnižším P/BV. Výsledky jsou navíc konzistentní, což znamená, že se se snižujícím P/BV výnosy pomalu zvyšují.

Tabulka 2: Průměrný roční výnos akcií podle decilů

\begin{tabular}{|c|c|c|c|c|c|c|c|c|c|c|}
\hline Decil & $\begin{array}{c}1 \\
\text { (nejvy̌šśi P/BV) }\end{array}$ & 2 & 3 & 4 & 5 & 6 & 7 & 8 & 9 & $\begin{array}{c}10 \\
\text { (nejnižší P/BV) }\end{array}$ \\
\hline Průměrný výnos v \% & $-4,3$ & -2 & 0,3 & 0,4 & 0,6 & 1,2 & 2,4 & 2,8 & 3,3 & 3,5 \\
\hline
\end{tabular}

Zdroj: Lakonishok, Shleifer, Vishny (1994)

Damodaran (2003) provedl výzkum pro období 1927-2001 a rozdělil je na tři navazující období. Z jeho výzkumu vyplývá, že akcie s nízkým P/BV překonávaly akcie s vysokým P/BV. Nutno podotknout, že v periodě, která zahrnovala Velkou depresi, výsledky byly nejméně jednoznačné a záleží tedy i na volbě období, které si pro zkoumání zvolíme. Jim O'Shaughnessy (2014) to vysvětluje tak, že akcie s nízkým P/BV jsou obecně akcie finančně slabých společností, které jsou riskantními investicemi.

Obdobně jako $\mathrm{P} / \mathrm{E}$, ukazatel $\mathrm{P} / \mathrm{BV}$ investorovi říká, jak vysoký násobek účetní ceny vlastního kapitálu platí za akcii. Jinými slovy se jedná o ocenění vlastního kapitálu trhem, kolik korun jsou investoři na trhu ochotni zaplatit za jednu korunu účetní ceny vlastního kapitálu. Výhoda proti ukazateli $\mathrm{P} / \mathrm{E}$ a modelům založených na zisku je, že je ukazatel $\mathrm{P} / \mathrm{BV}$ možno počítat $\mathrm{i}$ v prrípadě, když společnost nevykazuje zisk. Thomsett (2006) uvádí fakt, že rozvaha nezahrnuje některé významné položky jako je dlouhodobý leasing nebo závazky spojené s penzijním 
programem dané společnosti. Zahrnutí takových položek do rozvahy by ovlivnilo účetní hodnotu podniku. Dalším problémem je srovnávání společností na bázi účetní hodnoty mezi odvětvími, protože každé odvětví má jinou potřebu vlastního kapitálu. Pro lepší orientaci investora v hodnotách ukazatele, definuje Leonard (2016) průměrnou výši P/BV na americkém trhu v závislosti na průmyslovém odvětví (viz tabulka 3).

Tabulka 3: Průměrná výše P/BV podle odvětví v indexu S\&P 500

\begin{tabular}{|l|c|l|c|}
\hline \multicolumn{1}{|c|}{ Odvětví } & P/BV & \multicolumn{1}{c|}{ Odvětví } & P/BV \\
\hline Banky & 1,16 & Pojišt'ovnictví & 0,91 \\
\hline Biotechnologie & 7,50 & Elektronika & 2,01 \\
\hline Finanční služby & 1,73 & Doprava & 5,65 \\
\hline Zpracování potravin & 2,71 & Utility & 1,83 \\
\hline
\end{tabular}

Zdroj: Leonard N. Stern School of Business, 2016, upraveno.

Požadavek na nízkou hodnotu P/BV doplníme dalšími podmínkami. Gladiš (2015) uvádí dalších 6 kritérií, které by měl investor provádějící fundamentální analýzu sledovat. Jedná se o maximální výši ukazatele $\mathrm{P} / \mathrm{E} 15$, pravidelné vyplácení dividendy, poměr celkového dluhu k vlastnímu kapitálu maximálně 0,6 , běžná likvidita vyšší než 2 , stabilita zisků (průměrný růst za posledních pět let alespoň $4 \%$ ročně) a tržní kapitalizace alespoň 500 milionů dolarů. Damodaran (2003) upozorňuje, že akcie s nízkým P/BV nemusí být nutně levné, protože může existovat dobrý důvod pro nízkou hodnotu P/BV - konkrétně nízká hodnota návratnosti vlastního kapitálu (ROE). V krajním př́ípadě pokud byla návratnost vlastního kapitálu v minulosti a očekává se i v budoucnosti menší než jsou náklady na vlastní kapitál dané společnosti, ukazatel P/BV by měl být pod hodnotou 1. Damodaran tedy doporučuje (podobně jako Gladiš), pokud investor hledá podle ukazatele P/BV levné akcie, rozšiŕit požadavek na nízké P/BV o další kritéria. Konkrétně uvádí vysokou návratnost vlastního kapitálu. Doplňuje jej také požadavkem na nepř́liš velké zadlužení podniku.

\section{Metodika}

Do vzorku sledovaných akcií bylo zahrnuto 10 nejlikvidnějších titulů z Pražské burzy (podle objemu obchodů v Kč), které v roce 2014 tvořily 99 \% veškerého objemu obchodů. Jedná se o akciové tituly ČEZ, Komerční banka, Erste Group Bank, O2 ČR, Philip Morris ČR, CETV, Pegas Nonwovens, Fortuna, NWR a Vienna Insurance Group. Dalším obecným požadavkem fundamentální analýzy je, aby společnosti byly fundamentálně silné. Základním měřítkem je schopnost tvorby zisku, což je zároveň základním cílem každé akciové společnosti. Vyřazena byla tedy společnost CETV, která vykázala ve většině sledovaného období ztrátu a společnost NWR, která vstoupila na burzu až v roce 2008 a do roku 2014 měla 4 ztrátové roky. Společnost Fortuna vstoupila na burzu až v závěru roku 2010, a tudíž byla z důvodu krátké časové řady vyřazena. Zkoumaný vzorek tedy tvoří 7 titulů z Pražské burzy. Délka zvoleného období musí odpovídat základům fundamentální analýzy, tj. musí být dostatečně dlouhé, protože se daná analýza nesnaží předpovídat krátkodobé pohyby trhu. Davis, Aliaga-Diaz a Thomas (2012) ve svém výzkumu prokázali, že pomocí P/E není možné předvídat pohyby trhu v krátkém období 1 rok, ale daný model je statisticky významný až pro období 5-10 let.

Vzhledem k dostupnosti dat, námi zkoumané období začíná 31.12.2003 a končí 31.12.2014. Období bylo dále rozděleno na pětiletá období klouzavě (31.12.2003-31.12.2008, 31.12.2004 31.12.2009, atd.). Pro každé období byl spočítán průměrný reálný roční celkový výnos. Počítán je geometrický průměr, který správně vystihuje skutečnost, nebot' průměrného aritmetického výnosu by mohlo být dosaženo pouze za předpokladu nulové volatility ročních výnosů. Celkový výnos znamená jak kapitálový výnos, tak i dividendový výnos a reálný znamená 
očištění o růst indexu spotřebitelských cen (CPI) na základě dat z Českého statistického úřadu. Takový komplexní výpočet průměrného reálného ročního celkového výnosu nejlépe odpovídá skutečnosti, když investor dané akcie koupí a drží po určité období.

Zdrojem dat byla především databáze Patria, historické údaje o dividendách byly převzaty $\mathrm{z}$ jednotlivých webových stránek daných společností a př́ipadně $\mathrm{k}$ daným datům aktuální kurzy české koruny byly nalezeny na webových stránkách České národní banky, protože některé společnosti uvádí výši dividend pouze v měně mateřské společnosti (VIG, Erste Group Bank). K začátku každého 5-letého období je přebrána hodnota P/E (1) a P/BV (2), která byla vypočtena vždy k 31.12 předchozího roku (např. počáteční hodnota $\mathrm{P} / \mathrm{E}$ v roce 2004 , je tak hodnotou z 31.12.2003). Tento postup byl využit především z důvodu zveřejňování zisku, či velikosti (ceny) vlastního kapitálu k 31.12.

$$
P / E=\frac{P}{E P S},
$$

kde P je aktuální tržní cena akcie (vždy tedy k 31.12.),

EPS je poslední známý zisk na akcii vypočítaný jako čistý zisk společnosti za účetní období, který se vydělí průměrným počtem akcií společnosti v daném období.

$$
P / B V=\frac{P}{B V P S},
$$

kde P je aktuální tržní cena akcie (vždy tedy k 31.12.),

BVPS je poslední známá účetní cena vlastního kapitálu.

\section{Dosažené výsledky}

Pro vybrané tituly byl spočítán průměrný reálný roční celkový výnos klouzavě vždy za pět let. Vždy je tedy uveden titul s rokem, který označuje počáteční rok pětiletého období, průměrný výnos (p.a.) a hodnota ukazatele, tzn. P/E resp. P/BV (viz prŕloha 1).

Zcela zásadním výsledkem, který je jasně z tabulky vidět, je fakt, že skupina s nejnižším průměrným $\mathrm{P} / \mathrm{E} 9,04$ vykázala nejvyšší průměrný výnos p.a. 8,23 \%. Průměrné $\mathrm{P} / \mathrm{E}$ skupiny bylo proti dlouhodobému průměrnému $\mathrm{P} / \mathrm{E}$ Pražské burzy 14,02 výrazně nižší. Na druhé straně skupina s nejvyšším průměrným P/E 19,06 vykázala nejnižší průměrný výnos p.a. -2,86 \%. Průměrné $\mathrm{P} / \mathrm{E} 19,06$ je tedy výrazně nadprůměrné proti průměrnému $\mathrm{P} / \mathrm{E}$ na Pražské burze, které činí 14,02. Rozdíl ve výnosu je tedy 11,09 procentních bodů (p.b.). Dalším důležitým poznatkem z tabulky je, o kolik která skupina akcií překonala trh. Skupina s nejnižším průměrným $\mathrm{P} / \mathrm{E}$ překonala trh $\mathrm{v}$ průměru o $6,67 \mathrm{p}$. b., prostřední skupina $\mathrm{o} 2,65 \mathrm{p}$.b. a skupina s nejvyšším průměrným $\mathrm{P} / \mathrm{E}$ pouze o 1,48 p.b.. Můžeme i z hlediska překonání trhu konstatovat, že akcie s nejnižším P/E si vedly mnohem lépe než akcie s nejvyšším P/E (rozdíl mezi nimi 5,19 p.b.). Někdo by mohl namítnout, že je nesmysl, že všechny tři skupiny překonaly trh. Toto je však způsobeno tím, že vzorkem je pouze 7 titulů - byly vybrány pouze nejlikvidnější tituly a následně ještě odstraněny tituly, které opakovaně vykazovaly ztrátu. $Z$ tohoto pohledu je tedy možné, že i akcie s nejvyšším P/E překonaly trh. 
Variabilita výsledků byla kvantifikována za pomoci směrodatné odchylky výnosů. Menší směrodatná odchylka výnosů znamená ceteris paribus také menší riziko. Skupina s nejnižším P/E vykázala směrodatnou odchylku výnosů ve výši 27,74 p. b., zatímco skupina s nejvyšším P/E dosáhla směrodatné odchylky 30,29 p.b. Rozdíl mezi skupinami je 2,55 p.b. Nyní můžeme komentář $\mathrm{k}$ dosaženým výsledkủm dále rozšiřit o to, že skupina akcií s nejnižším P/E překonala svým výnosem skupinu akcií s nejvyšším P/E, navíc s nižší směrodatnou odchylkou výnosů. Stejným způsobem byla sestavena tabulka pro ukazatel P/BV (viz príloha 2).

Významným poznatkem analýzou akcií dle jejích P/BV je fakt, že skupina akcií s nejnižším průměrným $\mathrm{P} / \mathrm{BV}(1,17)$ výrazně překonala svým výnosem $(8,90 \%)$ skupinu s nejvyšším průměrným $\mathrm{P} / \mathrm{BV}(3,34)$, která vykázala výnos $-2,34 \%$. Průměrné $\mathrm{P} / \mathrm{BV}$ na Pražské burze je pro připomenutí 1,73 , takže vidíme, že skupina s nejnižším P/BV má skutečně velmi nízké průměrné $\mathrm{P} / \mathrm{BV} 1,17$ a pouze dva tituly $\mathrm{z}$ této skupiny vykázaly vyšší $\mathrm{P} / \mathrm{BV}$ než je historický průměr burzy. Rozdíl ve výnosu obou dvou skupin je 11,24 p.b. Dalším důležitým poznatkem $\mathrm{z}$ tabulky je, o kolik která skupina akcií překonala trh. Skupina s nejnižším průměrným $\mathrm{P} / \mathrm{BV}$ překonala trh v průměru o 7,70p.b., prostřední skupina o 1,58 p.b. a skupina s nejvyšším průměrným $\mathrm{P} / \mathrm{E}$ pouze o 1,31 p.b.. Můžeme i z hlediska překonání trhu konstatovat, že akcie s nejnižším P/BV si vedly mnohem lépe než akcie s nejvyšším P/E (rozdíl mezi nimi 6,39 p.b.). $\mathrm{V}$ př́ípadě ukazatele $\mathrm{P} / \mathrm{E}$ byl tento rozdíl o něco menší $(5,19$ p.b.). Pokud si jako cíl investování klademe překonat co nejvíce benchmark, jeví se ukazatel $\mathrm{P} / \mathrm{BV}$ jako lepší indikátor, podle kterého je možno vybírat levné akcie.

Podobně jako u ukazatele $\mathrm{P} / \mathrm{E}$ všechny tři skupiny překonaly trh. Toto je však způsobeno tím, že vzorkem je pouze 7 titulů - byly vybrány pouze nejlikvidnější tituly a následně ještě odstraněny tituly, které opakovaně vykazovaly ztrátu. $Z$ tohoto pohledu je tedy možné, že i akcie s nejvyšším P/BV překonaly trh. Je potřeba zmínit skutečnost, že ukazatel P/BV se skládá pouze z aktuální ceny akcie a účetní hodnoty vlastního kapitálu. Jinými slovy se snažíme předvídat budoucí výnos akcií podle toho, kolik korun stojí jedna koruna vlastního kapitálu. Jedná se tedy o obrovské zjednodušení a pochopitelně nemůže přinášet extrémně dobré výsledky tento ukazatel sám o sobě, protože zaprvé opomíjí velké množství kurzotvorných informací z globálního a odvětvového prostředí a informací o samotné společnosti a zadruhé kdyby takový jednoduchý způsob přinášel extrémně dobré výsledky, začali by jej používat všichni investoři a tím by byl efekt nízkého P/BV zrušen. Další omezení ukazatele P/BV týkající se výsledků je problematické určení účetní hodnoty vlastního kapitálu, která nemusí odpovídat tržní ceně. Dalším důležitým omezením, které je nutné brát na zřetel, je skutečnost, že existují rozdíly v typické výši P/BV mezi odvětvími. Pokud se však podíváme na historické údaje o ukazateli P/BV u jednotlivých společností, můžeme usoudit, že nejsou zásadní rozdíly ve výši $\mathrm{P} / \mathrm{BV}$ mezi odvětvími, pouze společnost Philip Morris ČR dlouhodobě vykazuje výrazně vy̌šsí průměrné $\mathrm{P} / \mathrm{BV}$ 3,47 než ostatní společnosti, jejichž $\mathrm{P} / \mathrm{BV}$ se dlouhodobě pohybuje přibližně kolem průměrného $\mathrm{P} / \mathrm{BV}$ pro Pražskou burzu $(1,73)$.

Cílem př́spěvku bylo potvrdit či vyvrátit stanovené hypotézu, že akcie na českém trhu s nízkým poměrem $\mathrm{P} / \mathrm{E}$ překonávají trh a vykazují vyšší celkový průměrný roční reálný výnos než akcie s vysokým poměrem $\mathrm{P} / \mathrm{E}$. Potvrzení této hypotézy přináší tabulka 4 , která srovnává výsledky akcií dle výše $\mathrm{P} / \mathrm{E} \mathrm{s}$ trhem a jejich rizikovost. 
Tabulka 4: Srovnání výnosu akcií dle P/E

\begin{tabular}{|c|c|c|c|}
\hline & $\begin{array}{l}\text { Průměrný reálný } \\
\text { pětiletý výnos za } \\
\text { sledované období } \\
(2003-2014)\end{array}$ & $\begin{array}{c}\text { Výnos nad index PX-TR } \\
\text { za sledované období } \\
(2003-2014)\end{array}$ & $\begin{array}{l}\text { Směrodatná odchylka } \\
\text { reálných pětiletých } \\
\text { výnosů (p.a.) za } \\
\text { sledované období } \\
\text { (2003-2014) } \\
\end{array}$ \\
\hline Skupina akcií s nejnižším P/E & $8,23 \%$ p.a. & 6,67 p.b. & 27,74 p.b. \\
\hline Skupina akcií se středním $\mathbf{P} / \mathbf{E}$ & $0,58 \%$ p.a. & 2,65 p.b. & 30,91 p.b. \\
\hline Skupina akcií s nejvyšším P/E & $-2,86 \%$ p.a. & 1,48 p.b. & 30,29 p.b. \\
\hline
\end{tabular}

Zdroj: vlastní výpočty

Z dosažených výsledků je zřejmé, že si skupina akcií s nejnižším $\mathrm{P} / \mathrm{E}$ vedla výrazně lépe než skupina akcií s nejvyšším P/E (o 11,09 p.b.) a to navíc za podstoupení nižšího rizika vyjádřeného směrodatnou odchylkou. Skupina s nejnižším $\mathrm{P} / \mathrm{E}$ rovněž překonala svým průměrným ročním výnosem benchmark v podobě indexu PX-TR o 6,67 p.b.

Analogicky další zkoumaná hypotéza byla zaměřena na indikátor $\mathrm{P} / \mathrm{BV}$, resp., že akcie na českém trhu s nízkým poměrem $\mathrm{P} / \mathrm{BV}$ překonávají trh a vykazují vyšší celkový průměrný roční reálný výnos než akcie s vysokým poměrem P/BV. Obě hypotézy byly empirickým výzkumem potvrzeny a lze tak tvrdit, že oba ukazatele jsou vhodným indikátorem (vodítkem) při rozhodování o zařazení těchto tiulů (nízká hodnota $\mathrm{P} / \mathrm{E}$, resp. $\mathrm{P} / \mathrm{BV}$ ) do portfolia.

Obdobné výsledky přináší i analýza akcií na základě ukazatele P/BV (viz tabulka 5), kdy skupina akcií s nejnižším P/BV významným způsobem překonala svým průměrným výnosem skupinu akcií s nejvyšším P/BV (o 11,24 p.b.). Rovněž skupina akcií s nejnižším P/BV překonala svým průměrným ročním výnosem benchmark o 7,70 p.b.

Tabulka 5: Porovnání výnosu akcií dle P/BV

\begin{tabular}{|l|r|r|r|}
\hline & $\begin{array}{c}\text { Průměrný reálný } \\
\text { pětiletý výnos } \\
\mathbf{( 2 0 0 3 - 2 0 1 4 )}\end{array}$ & $\begin{array}{c}\text { Výnos nad index PX-TR } \\
\text { za sledované období } \\
\mathbf{( 2 0 0 3 - 2 0 1 4 )}\end{array}$ & $\begin{array}{c}\text { Směrodatná odchylka } \\
\text { reálných pětiletých } \\
\text { výnosů (\% p.a.) } \\
(\mathbf{2 0 0 3 - 2 0 1 4 )}\end{array}$ \\
\hline Skupina akcií s nejnižším P/BV & $8,90 \%$ p.a. & 7,70 p.b. & 30,40 p.b. \\
\hline Skupina akcií se stř́edním P/BV & $0,17 \%$ p.a. & 1,58 p.b. & 24,68 p.b. \\
\hline Skupina akcií s nejvyšším P/BV & $-2,34 \%$ p.a. & 1,31 p.b. & 33,14 p.b. \\
\hline
\end{tabular}

Zdroj: vlastní výpočty

Empirická analýza potvrdila obě stanovené hypotézy, tzn., že akcie na českém trhu s nízkým $\mathrm{P} / \mathrm{E}(\mathrm{P} / \mathrm{BV})$ překonávají trh a dosahují vyššího reálného výnosu než tituly s vysokým $\mathrm{P} / \mathrm{E}$ (P/BV). V obou př́padech bylo potvrzeno, že čím nižší hodnota uvažovaných indikátorů fundamentální analýzy, tím vyšší výnos, resp. nadvýnos nad sledovaný benchmark. Nutno ovšem podotknout, že do analýzy nevstupovaly všechny tituly Pražské burzy, ale pouze 7 nejlikvidnějších titulů, kdy byly vyřazeny ztrátové společnosti (CETV, NWR) a společnost Fortuna, která vstoupila na Pražskou burzu v průběhu sledovaného období. Lze tedy tvrdit, že potvrzení hypotéz se týká především stabilních společností (v našem př́ípadě takové společnosti, které mají největší podíl na likviditě trhu, resp. na objemu obchodování), které dlouhodobě dosahují zisku. Dosažené výsledky je potom možné aplikovat i na zahraniční trhy (především díky „univerzálnosti“ uvažovaných ukazatelů). 


\section{Diskuze a závěr}

Dosažené výsledky potvrzují, že i na českém trhu akciové tituly s nízkým $\mathrm{P} / \mathrm{E}$, resp. P/BV přinášejí investorovi vyšší míru výnosnosti a to dokonce při nižší míře rizika. Navíc tyto tituly více překonávají trh.

Pokud bychom se zaměřili na srovnání dosažených výsledků se zahraničními studiemi, lze konstatovat, že výsledky jsou obdobné. Siegel (2014) zkoumal výnosy indexu S\&P 500 od roku 1957 do 2012. Akcie rozdělil podle výše P/E do kvantilů, kdy akcie s nejnižším P/E vykázaly průměrný výnos $12,92 \%$, zatímco u akcií s nejvyšším P/E to bylo jen 7,86 \%. Rozdíl mezi těmito skupinami je 5,06 p.b. V této práci byl rozdíl mezi skupinou s nejnižším a nevyšším P/E dokonce 11,09 p.b., což je dvakrát více. Nicméně závěr poskytují obě studie podobný, že akcie $\mathrm{s}$ nízkým $\mathrm{P} / \mathrm{E}$ přináší vyšší výnosy než akcie $\mathrm{s} \mathrm{P} / \mathrm{E}$ vysokým.

Výsledky práce jsou také konzistentní s prací autorů Davis, Aliaga-Diaz, Thomas (2012), kteří zkoumali americký trh (index S\&P 500 v letech 1926-2011) s cílem zjistit použitelnost různých indikátorů, včetně běžného $\mathrm{P} / \mathrm{E}$. Pomocí běžného $\mathrm{P} / \mathrm{E}$ dokázali vysvětlit $38 \%$ rozptylu následných desetiletých výnosů indexu $\mathrm{S} \& \mathrm{P} 500$, ale pouze $8 \%$ rozptylu následných ročních výnosů. V dlouhém období je tedy možné použít ukazatel $\mathrm{P} / \mathrm{E}$ pro předpověd' budoucích výnosů. K podobnému závěru, avšak pro 5-leté období, které je obecně považováno za období dlouhé, dospěla také tato práce. Výsledky práce se rovněž téměř shodují se studií Damodarana (2003), který na indexu S\&P 500 v letech 1952 - 2001 ukázal, že skupina akcií s nejnižším P/E překonala skupinu akcií s nejvyšším P/E o $9-10$ p.b. (což přibližně odpovídá výsledkům této práce, kde byl rozdíl 11,09 p.b.). Obdobných výsledků dosáhnul i Knopers (2014) u indexu Euronext, kde hodnotové akcie (akcie s nízkým P/E) překonaly v období 1995 - 2013 akcie růstové (akcie s vysokým P/E) o 4,15 p.b. ročně. Výsledky z českého trhu byly potvrzeny i Tarazi a Ahmand (2012) zkoumajících Tokijskou burzu v Japonsku, kteří také dospěli k závěru, že je možné podle výše P/E předvídat budoucí výnosy. Lakonishok, Shleifer, Vishny (1994) zkoumali 2.700 akciových titulů z amerických burz NYSE a AMEX v období 1968-1989. Vždy seřadili akcie do decilů od decilu s nejnižším P/BV po nejvyšší P/BV (viz tabulka 2) a zkoumali následné pětileté výnosy (obdobně zde). Akcie s nejnižším $\mathrm{P} / \mathrm{BV}$ dosáhly průměrného výnosu $-4,3$ \%, zatímco skupina s nejvyšším P/BV 3,5 \%. Rozdíl činí 7,8 p.b. Ve výzkumu této práce byl vypočítán tento rozdíl 11,24 p.b, a tudíž poukazuje na ještě lepší použitelnost ukazatele P/BV při předpovědi budoucích výnosů. Damodaran (2003) zkoumal použitelnost ukazatele P/BV na amerických akciích za období 1927-2001, rozdělil jej na tři dílčí. Ve všech obdobích překonaly akcie s nízkým P/BV akcie s vysokým P/BV (v prvním období o 6 p.b., ve druhé o 9 p.b. a ve třetím o 5 p.b.). V porovnání s touto studií $(11,24$ p.b.) jsou výsledky konzistentní, nicméně rozdíly mezi skupinami jsou v Damodaranově studii o něco menší. O'Shaughnessy (2014) to vysvětluje tím, že společnosti s nízkým P/BV jsou obecně finančně slabé, a tudíž si v dobách medvědího trhu nevedou dobře. Dokazuje to svým výzkumem za období 2007-2009, kdy si akcie s nízkým P/BV proti akciím s vysokým P/BV dokonce vedly o 5,27 p.b. hůře. V tomto období velmi výrazně poklesla i Pražská burza, a tudíž tímto efektem nízkého P/BV $\mathrm{v}$ době medvědího trhu je pravděpodobně do jisté míry zatížen i výzkum v této práci. Capaul, Rowley, Sharpe (1993) zkoumali nadvýnos akcií s nízkým P/BV nad tržní index v různých zemích světa včetně evropských států v letech 1981-1992. Tento nadvýnos nad tržní index byl nejvyšší v Japonsku (o 3,43 p. b.) a nejnižší v USA a UK (1,06 p.b. a 1,09 p.b.). Pro Evropu celkově to bylo 1,30 p.b. a pro celý svět 1,88 p.b. Ve studii této práce byl nadvýnos akcií s nízkým P/BV nad benchmark dokonce 7,70 p.b., což je dvakrát více než v Japonsku, kde byl nadvýnos nejvyšší. Opět se můžeme vrátit k vysvětlení, že se jedná o poměrně malý vzorek dat a že byly vyloučeny z výzkumu některé ztrátové společnosti. Nicméně se výsledky shodují, že je možné výběrem akcií s nízkým P/BV porazit benchmark. 
Diskuzi o použitelnosti ukazatele P/BV lze shrnout tak, že akcie s nízkým P/BV v dlouhém období překonávají akcie s P/BV vysokým, existují však období, kdy si akcie s nízkým P/BV vedou hưře - čím větší a dlouhodobější propady akciových trhů, tím hůře si akcie s nízkým P/BV vedou v porovnání s akciemi s P/BV vysokým. Avšak pouze Velká deprese dokázala ovlivnit dlouhodobé výsledky, propad trhů v roce 2008 dlouhodobé výsledky ovlivnit nedokázala - v žádné z uvedených studií, ani výsledky výzkumu této práce.

Př́spěvek přináší potvrzení toho, že základní ukazatele $\mathrm{P} / \mathrm{E}$ a P/BV jsou jednoduchými indikátory, které mohou investorovi pomoci nalézt vhodné akcie pro zařazení do jeho portfolia, s tím, že tituly s nižšími hodnotami těchto ukazatelů dosahují na pětiletém investičním horizontu vyššího výnosu s nižší mírou rizika než tituly s průměrnými či vysokými hodnotami. Dalším možným rozšířením tohoto výzkumu je např. rozdělení titulů dle jednotlivých odvětví (na to je ale pražský trh př́liš malý), stanovení určitých průměrných hodnot, resp. „efektivních hodnot", které budou vycházet jednak z cen a vah jednotlivých titulů v odvětví ale i srovnání např. s cenou vybraného odvětvového benchmarku.

\section{Literatura}

[1] BHARGAVA, V. and D. K. MALHOTRA, Do Price-Earnings Ratios Drive Stock Values? Journal of Portfolio Management, Vol. 33, Issue1, p. 86-92, ISSN:

[2] CAPAUL, C., I. ROWLEY and W. F. SHARPE, 1993. International Value and Growth Stock Return. Financial Analyst Journal, Volume 49, Issue 1. ISSN 0015-198X.

[3] CLAESSENS, S., G. DELL'ARICCIA, D. IGAN and L. LAEVEN, 2010. Cross-Country Experience and Policy Implications from the Global Financial Crisis. Economic Policy, Vol. 62. PP. 269-93. ISSN: 1468-0327.

[4] DAMODARAN, A., 2003. Investment Philosophies. New Jersey: John Wiley \& Sons, Inc. ISBN 978-11-182604-94.

[5] DELL' ARRICIA, G., D. IGAN, L. LAEVEN and H. TONG, 2013. Policies for Macrofinancial Stability: Dealing with credit boom and busts. In Claessens, S., Kose, M., A., Laeven, L., Valencia, F. Financial Crises, Consequences and Policy Responses. International Monetary Fund, 2014. ISBN: 978-1-47554-340-7.

[6] DAVIS, J., R. ALIAGA-DÍAZ and CH. THOMAS, 2012. Forecasting stock returns: What signals matter, and what do they say now? [online]. Valley Forge: The Vanguard Group, [cit. 2016-12-26]. Dostupné z: https://personal.vanguard.com/pdf/s338.pdf

[7] De BONDT, W. F. M. and R. THALER, 1985. Does the Stock Market Overreact? The Journal of Finance, vol. 40, no. 3, 1985, pp. 793-805. Dostupné z: www.jstor.org/stable/2327804.

[8] GLADIŠ, D., 2015. Akciové investice. Praha: Grada, 2015. Investice. ISBN 978-80-2475375-1.

[9] HELLMAN, N., 2000. Investor Behaviour. Stockholm school of economics: Stockholm. ISBN 91-7258-543-9.

[10] HOLMAN, R., 2002. Mikroekonomie: Středně pokročilý kurz. Praha: C. H. Beck. ISBN 80-7179-737-5.

[11] KNOPERS, F., 2014. Value Investing: Evidence from the Dutch Stock Market [online]. Enschede.

[cit.

2016-12-26].

Dostupné

$\mathrm{z}:$ 
http://essay.utwente.nl/65834/1/knopers_MA_mb.pdf. Master Thesis. University of Twente.

[12] LAKONISHOK, J., A. SHLEIFER and R. VISHNY, 1994. Contrarian Investment, Extrapolation, and Risk, Journal of Finance [online], New York, 49(5) [cit. 2016-12-26]. Dostupné z: https://greenbackd.com/2009/11/25/contrarian-investment-extrapolation-andrisk-lsvs-two-dimensional-classifications/

[13] LEONARD, N., 2016. Price and Value to book ration by sector (US). [online]. New York Stern School of Business. [cit. 2016-12-20]. Dostupné z: http://pages.stern.nyu.edu/ adamodar/New_Home_Page/datafile/pbvdata.html

[14] NITZSCHE, D. and K. CUTHBERTSON, 2008. Investments. 2nd ed. USA: Hoboken: John Wiley \& Sons. ISBN 978-0-470-51956-1.

[15] O'SHAUGHNESSY, J., 2014. Price-to-Book Value Ratios: A Long-Term Winner with Long Periods of Underperformance. What Works on Wall Street [online]. [cit. 2016-1226]. Dostupné z: http://jimoshaughnessy.tumblr.com/post/103140701394/price-to-bookvalue-ratios-a-long-term-winner

[16] PIKE, R., J. MEERJANSSEN and L. CHADWICK, 1993. The appraisal of ordinary shares by investment analysts in the UK and Germany, Accounting and Business Research. Vol. 23, Autumn, pp 489-499.

[17] REJNUŠ, O., 2012. Peněžní ekonomie. Brno: CERM. ISBN 978-80-214-4415-7.

[18] SIEGEL, J., 2014. Stocks for the long run: the definitive guide to financial market returns. Fifth edition. New York: McGraw-Hill Education. ISBN 00-718-0051-4.

[19] SIEGEL, J., 2002. The Rise in Stock Valuations and Future Equity Returns. In: JeremySiegel.com [online]. [cit. 2016-12-26]. Dostupné z: http://www.jeremysiegel.com/index.cfm?fuseaction=Resources.Download\&resourceID= 6240

[20] SIEGEL, J., 2016. The Shiller CAPE Ratio: A New Look. Financial Analysts $\begin{array}{llllllll}\text { Journal [online]. } & 72(3), & 4 & - & 50 & \text { [cit. 2016-12-26]. Dostupné } & \mathrm{z} \text { : }\end{array}$ http://www.cfapubs.org/doi/pdf/10.2469/faj.v72.n3.1

[21] SHEN, P., 2000. The P/E Ratio and Stock Market Peformance. Federal Reserve Bank of Kansas City: Economic Review, number 4, volume 36. Dostupné z: https://pdfs.semanticscholar.org/99cd/d22a2ea2b0e7215efb5bdee3eab690683842.pdf

[22] ŠIRU゚ČEK, M., 2015. Kauzální vztah peněžní nabídky a amerického akciového trhu, Mendelova univerzita v Brně, 96 s. ISBN 978-80-7509-304-2.

[23] TARAZI, R. and N. AHMAD, 2012. The Relationship Among The Fundamental Variables and Macroeconomics Variables with Stock Return (September 7, 2012). Dostupné z: SSRN: https://ssrn.com/abstract=2143144

[24] THOMSETT, M., 2006 Fundamental analysis. Hoboken, N.J.: J. Wiley. ISBN 978-0471754-466.

[25] VERGOSSEN, R. G. A., 1993. The use and perceived importance ofannual reports by investment analysts in the Netherlands. European Accounting Review, Vol. 2, No. 2, pp. 219-244.

[26] VESELÁ, J., 2011. Investování na kapitálových trzích. 2., aktualiz. vyd. Praha: Wolters Kluwer Česká republika. ISBN 978-80-7357-647-9. 
[27] VOREK, M., 2009. Does High Price Earning Ratio Predict Future Falls of Stock Price? [online]. University of Economics in Prague. [cit. 24.4.2017]. Dostupné z: https://www.yumpu.com/en/document/view/32463744/does-high-price-earnings-ratiopredict-future-falls-of-stock-icabrcom

[28] VORWERG, J., 2015. Value vs. Growth: Evidence from the German Stock Market [online]. Enschede. [cit. 2016-12-26]. Dostupné z: http://essay.utwente.nl/67293/1/Vorwerg_BA_Management\%20and\%20Governance.pdf. Bachelor thesis. University of Twente. Vedoucí práce Xiahong Huang. 


\section{Příloha 1}

('qd)

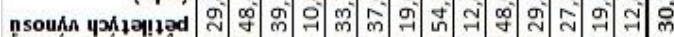

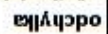

eupposaus

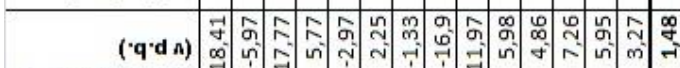

II-Kd peu souhA

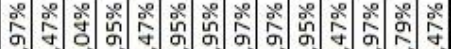

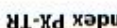

e'd

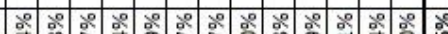
Ausơuñud

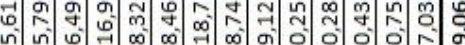

$\exists / d$

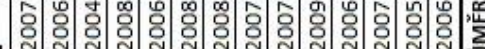

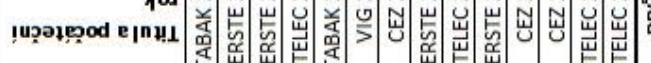

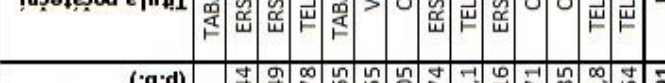

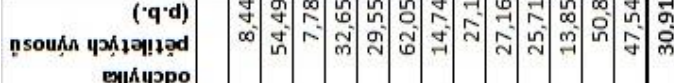

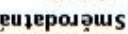

$(\cdot q \cdot d n)$

\&I-Kd peu souhî

४I-Kd кәри

mे
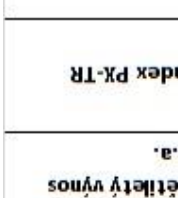

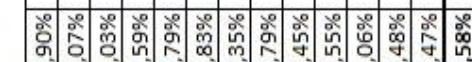

Áuวundd

/d

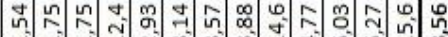

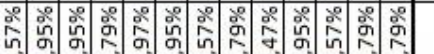

(1)

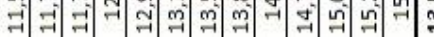

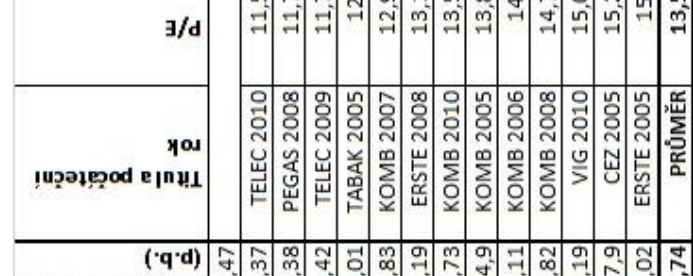

('qd) f

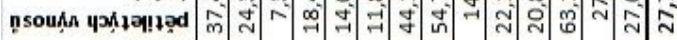

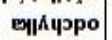

еuцерозатs

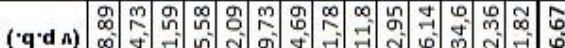

II-Kd peu souń

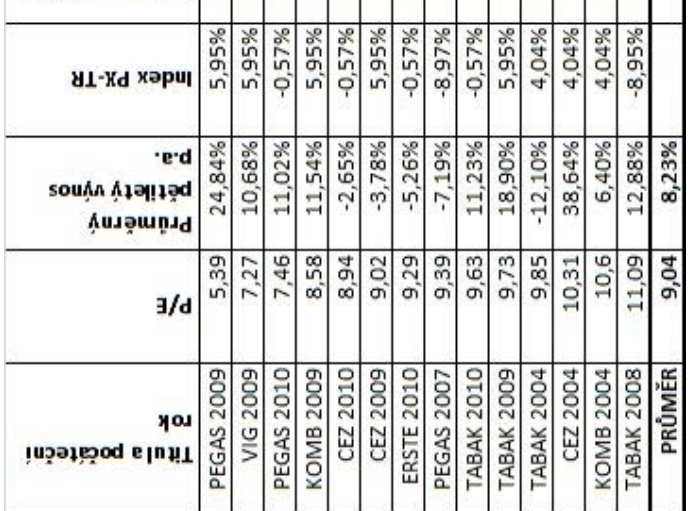




\section{Příloha 2}

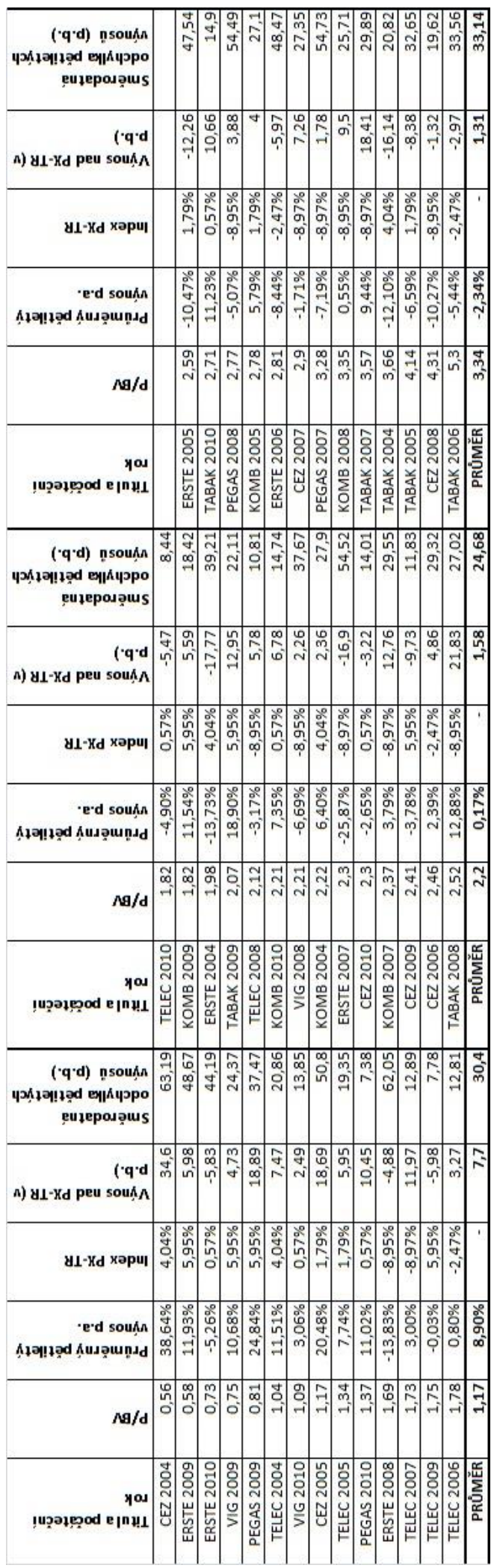

